COLLOQUIA THEOLOGICA OTTONIANA 1/2019, s. 27-39

DOI: $10.18276 /$ cto.2019.1-02

\title{
IN SEARCH SPIRITUALITY BIOLOGY
}

Gratia non tollit naturam, sed eam supponit et perficit

(św. Tomasz z Akwinu)

\author{
Wiesław Dyk* \\ Wydział Humanistyczny Uniwersytetu Szczecińskiego
}

\section{Introduction}

Emotions are an integral part of human's biology and their activity actuates nearly every system of the brain. In "M. Tulli Ciceronis Disputationum Libri Quinque" book 3, condition of a spirit is indicated and defined as adefectus, contemporarily translated as affectus. Following statement is being invoked there: "qualis autem homo adfectus esset, talem eius esse orationem" which means: "As the condition of a man's spirit, so it is his speech". In his research, neurobiologist Joseph LeDoux is pointing out directly that genesis of emotions is being carried out independently from rationality. However, in human brain emotions and thoughts are combined creating the foundation for spirituality of Man ${ }^{1}$. I agree with LeDoux, defining this state as emotional brain. Neocortex development in human brain including its systemic relations to previous structures and emotional

* Ks. dr hab. Wiesław Dyk prof. US - kierownik Zakładu Filozofii Przyrody i Bioetyki, Instytut Filozofii, Wydział Humanistyczny Uniwersytetu Szczecińskiego. E-mail: wdyk@wp.pl.

1 I do not define spirituality as contemporary theologians do. Spirituality in the context of this article is a natural, evolutionary stage of Homo sapiens sapiens development. This is pointed out by LeDoux in context of neurobiology and we know that the process of evolution is not over yet. It may be like LeDoux is claiming: the more advanced form of rationality and emotions will take place. It is an evolutionary course to the stage of homo sapientissimus. 
functions, would be the key point of interest in search for evolution process of homo spiritual or in its creative aspect - homo creator.

Analyses regarding development of spirituality refer to Konrad Lorenz's terminology where notion of spirituality is very close to notion of culture. In reference to previously developed brain structures, human species have already been attributed with inherited emotional reactions to certain stimuli but it did not differentiate it from animals. From this point on, culture created by Man can be discussed. Evolution of neocortex gave the potential for self-reflection. Through this process structures complexed enough for taking creative stand in natural environment has been developed. This fact proved Man's uniqueness in living world. At this stage Konrad Lorenz is talking about spirituality of human kind applying notion of so-called fulgurations. In this context, fulguration refers to high-level function integrity of low-level structures functioning independently ${ }^{2}$. Knowledge gained in phylogenetic process gave foundation to reorganize human brain. Ability to think is a result of a subsequent fulguration ${ }^{3}$. Thus, in the cultural process, in phylogenesis, human behaviour standards have developed.

The reason for dedication significant amount of space to ethology when the title of the article indicates main interest in neurobiology is that Lorenz is being negative when predicting future of human culture and spirituality. According to him, neither contemporary culture nor present condition of human spirit give any chance for further development and life of human kind on Earth. He claims that the pathological character of culture's downfall is a result of human spirit's disease and it requires life sciences insight ${ }^{4}$. In regards to this issue, Lorenz does not only expect but demands to bring down the wall dividing life sciences and humanities. In the consequence natural scientists will be introduced to the realm of values and the humanists will be freed from the boundaries of idealism. Claim that human can only be understood in context of natural sciences must be discarded.

\section{Genesis of emotions and language}

Joseph LeDoux indicates that in order to understand the nature of emotions, it is the best to treat them like biological functions of nervous system, i.e. as

2 K. Lorenz, Odwrotna strona zwierciadla, Warszawa 1977, p. 293.

3 Ibidem, p. 295.

4 Ibidem, pp. 55-57. 
brain functions. He advises to take the brain structure as a result of evolution in specific environmental conditions. When neocortex has been developed in mammals, higher mental functions like thinking, mind and comprehension came to existence. It is a fact that the maximum development occurred in Homo sapiens sapiens. Regarding the emotions however - although not all brains are the same neural organisation being the foundation for emotional behaviour in all mammals is the same or at least very similar. Even though the brain is still undergoing evolution, structures responsible for emotions are not a subject for changes for some time now. In neurobiology of spirituality it is worthwhile to take special notice of the development of emotional functions after the cerebral cortex has been formed.

Jerzy Vetulani claims that evolution of brain from a shark to a human took around 400 million years 5 . Formation of neocortex around 3 million years ago allowed occurring of two brain functions i.e. emotions and reason. Centres of emotions are located in hippocampus, amygdala and hypothalamus (here are located the centres of emotions, pleasure, moods and motivations). Cerebral cortex, notably frontal lobe is a centre of rational brain (thinking, predicting, and intellect) ${ }^{6}$. In such organized and functioning brain emotional processes and consciousness are running through the lobe and are the foundation of what Vetulani calls - a way for a soul to express itself ${ }^{7}$. Evolutionary gap between animals and human rests on development of temporal and frontal lobes and creates this huge difference between animal kingdom and Homo sapiens. More specifically, Vetulani enumerates ${ }^{8}$ :

1. Difference in brain dimensions and EQ (encephalization quotient) - ratio between the brain size and the body mass.

2. Transformation of the human brain old structures into new centres, e.g. new regions in entorhinal cortex.

3. Frontal lobe as the central executive of the brain takes up to $29 \%$ of the entire brain in human, while in chimpanzee it is $17 \%$ and in macaque $-11.5 \%$.

4. Enlargement of the structure and improvement of frontal lobe caused reduction of other lobes, e.g. optical lobe (in macaque it is $17 \%$ while in human only $1.5 \%$ ).

5 J. Vetulani, Mózg: fascynacje, problemy, tajemnice, Kraków 2010, p. 41.

${ }^{6}$ Ibidem, p. 42.

7 Ibidem, p. 39.

8 Ibidem, pp. 46-50. 
5. In temporal lobe associated with speech, an asymmetry occurred in human brain. Despite the existence of Wernicke's area (it is better developed in left front temporal lobe) and Broca's area in ape's brains, due to the frontal lobe being symmetrical, even when they possess ability to speak, they can only use gestures and symbolic language.

6. Articulated speech and vocalization in human was possible by the asymmetry in temporal lobe and formation of vocal apparatus. Cranial development contributed to creation of more space in the cervix which helped fitting all anatomical structures responsible for articulated speech ${ }^{9}$.

7. Verbal communication between people makes human incomparable to animal kingdom ${ }^{10}$.

8. Vast and specific dopaminergic innervation occurred which enabled evolutionary selective expansion in neocortex.

It seems that development of latter brain structures i.e. associated with speech and intelligence is an evolutionary leap to the new world of Homo sapiens sapiens. However, contrary to cognitivists, Joseph LeDoux states that the mind without emotions can hardly be called a mind; without emotions it is difficult to talk about consciousness. Emotions are a sort of thinking ${ }^{11}$. Similar to Vetulani, he points out the mutual relationship between emotional reactions and rational cognitive responses due to verbal regulation. Using the language, emotional reactions can be toned down but we can also induce them in our audience ${ }^{12}$.

Human and animal affinity can be seen in emotions being the essence of their existence - their souls. Reason and language are of lesser meaning as emotions have been created on the previous stage of evolution. According to LeDoux, souls of human and animals in neurobiological context are understood as emotional creations. In the aspect of neurobiological analyses, animal souls are emotionally determined to preserve life. In human, spiritual sphere accounts for emotions and rational arguments which mean that in its decisions and actions, soul exceeds far beyond biological and psychological sphere. From natural sciences point of view,

9 Ibidem, p. 50. Human larynx is located deep inside the throat and oral cavity is bigger which enables use of wider variety of sounds to be articulated. Human tongue innervation and musculature enables precise and quick control during fluent word generation. In top of that, humans produce sounds on exhaust, while animals do it on aspiration and expiration. In: P. Gärdenfors, How Homo became sapiens. On evolution of thinking, Oxford 2006.

${ }^{10}$ G. Roth, U. Dicke, Evolution of the Brain and Intelligence, "Trends in Cognitive Science" 9 (2005), No. 5, pp. 250-257.

11 J. LeDoux, Mózgowe interakcje poznawczo-emocjonalne, in: Natura emocji, eds. P. Ekman, R. Davidson, Gdańsk 2002, p. 191.

12 J. Vetulani, Mózg..., p. 52. 
however, product of all abstract thinking, poetic and mathematic abilities have no relation to protection against imminent danger and thrive for survival.

Peter Gärdenfors states that without language, various mind functions are possible and that lack of self-awareness and rich inner world prevents development of language ${ }^{13}$. He claims that language is a powerful tool for revealing of, in layman's terms, what is going on in our heads ${ }^{14}$. Externalisation of inner world was possible due to community, creation of culture and living in that culture. Hence, it is necessary to present arguments for the sense of life, moral behaviour in evolutionary context. Morality demands inclusion of what is going on in our heads - morality demands the mind.

\section{Morality in context of evolution of mind}

Michael Tomasello attempted to find the source of "human thinking" genesis in evolutionary context and claims sceptically that he cannot find any previous behaviour forms from which due to mutation and selection, we could derivate existing stage of development. He claims that cognition and human thinking emerged by accident ${ }^{15}$. Diversity and variability of environment created new chances and threats hence a mind capable of recognising the existing, specific situation and search for survival occurred.

Differently from Tomasello, Michael Gazzaniga exhibits deterministic approach to genesis and function of human brain. Brain is a result of evolution from its natural foundation, i.e. chemical and physical. Hence, the latter brain structures and functions are logical consequence to this premise. Determinism in physics is the rationale for deterministic approach in neurobiology ${ }^{16}$. Neurobiological determinism manifests itself due to the fact that brains in existing physical conditions function deterministically. If so, how can a human being be responsible for its own decisions and actions? Gazzaniga deterministically defines brain functioning in a specific social situation. Social contract determines relations between individuals and within its frame, deterministic brain can make free and aware decisions, therefore being accountable for them.

\footnotetext{
13 P. Gärdenfors, Jak Homo stat się sapiens, Warszawa 2010, p. 245.

14 Ibidem, p. 247.

15 M. Tomasello, Historia naturalna ludzkiego myślenia, Kraków 2015, p. 215.

16 M. Gazzaniga, The Law and Neuroscience, "Neuron” 60 (2008), No. 3, pp. 412-415.
} 
External physical conditions and laws of nature determine not only human behaviour but also human self. According to Gazzaniga, determined world and mind being result of physical processes in brain, cannot restrict free choices and human accountability ${ }^{17}$. He states that the source of free will should be looked for in the relations with other people and in the behaviour in the environment, not in the brain ${ }^{18}$. Man attributed with free will is somewhat inscribed in the world he lives in and in his life and development, he depends on social context. Not only physical and biological but moreover cultural and social characteristics allow him to gain a new attribute i.e. freedom, personal identity in surrounding world among other people and the accountability that follows. In evolutionary process, brain has been shaped from different specialised modules, mostly genetically determined but it undergoes modelling through ontogenesis ${ }^{19}$. Gazzaniga advises that there are no hierarchical relations between modules ${ }^{20}$. Brain functions through competition between its specific structures. It is not possible to find brain's central command. Potential to shape and evolutionary specialisation of primate's brain functions gave humans a great advantage in changing surrounding. This advantage is founded in the web structure of brain giving great ability to process data and fast communication in global network frames.

To support his thesis about internal unity and identity of human person, Gazzaniga refers to theory of left hemisphere interpreter. According to this theory, left hemisphere is dominant in ex post arrangement of feelings. Based on them history of personality is automatically and unconsciously created ${ }^{21}$. Although Gazzaniga is not referring directly to religion, discussing issues like cognition, free will, mind, consciousness, responsibility and identity creates vast spectrum of subject around human nature and it religious foundation. Gazzaniga concludes that in deterministic world there are no obstacles to acclaim compatibilism, i.e. to acknowledge free will. In society new interactions between people are being generated therefore new rules are necessary to allow social coexistence ${ }^{22}$. Freedom and accountability are foundation for emergence of these rules and simultaneously emergence of social mind being the basis for empathy and morality to shape.

17 This issue is discussed widely in his book: Who's in Charge? Free Will and the Science of the Brain, New York 2011.

\footnotetext{
18 M. Gazzaniga, Istota człowieczeństwa. Co sprawia, że jesteśmy wyjątkowi, Sopot 2011, p. 112.

19 Ibidem, p. 63.

20 Ibidem, p. 64.

${ }^{21}$ Ibidem, p. 91.

22 Ibidem, p. 118.
} 
When David Chalmers explains genesis of consciousness in nature, he claims that state of mind is conscious when a feeling of being in the state of mind exists. When the state of mind is bound with quality experience then it is conscious $^{23}$. Suspending the propriety of reductionist approach to explaining consciousness, he concludes that biological properties supervene on physical properties. He explains that supervenience is relation between two sets of properties: properties of higher order and basic properties of lower order ${ }^{24}$. He then points out that it does not explain why in the process of evolution sentient beings rather than mindless zombies have emerged ${ }^{25}$. Reasoning that the consciousness emerged from physical systems would be correct by acclaiming the thesis that if God would set up all facts in our world, the biological facts would be an extra, free of charge deal ${ }^{26}$. Supernatural intervention is required in the reductionist procedure of logic argumentation. Chalmers is aware that genesis of consciousness and human thinking will always be out of reach for physical approach. He dismisses the reductionist approach for explaining the origination of mind $^{27}$.

Ability to think and talk distinguish human from primates and clearly shows that morality sets up primary aim as to persevere in communal life with all other individual life goals as subjective. Therefore, relations in community demanded freedom and obedience to ethical code. Choosing to act was not directed by personal expectations. Superior goals had to clash with current possibilities and egocentric needs. Peter Gärdenfors shows how in evolutionary context, egocentric behaviour was eliminated even for a short term leading to so-called prisoner dilemma, i.e. when the lack of cooperation of individuals is causing deterioration of everyone life's quality. Gärdenfors claims that emotions like shame and love and social values like trust and honesty emerge evolutionarily to prevent us from benefiting from the prisoner dilemma ${ }^{28}$. He adds that feelings and biological drives may lead to conflict in both nature and culture and he concludes that the morality cannot be fully biologically grounded ${ }^{29}$.

${ }^{23}$ D. Chalmers, Świadomy umysł w poszukiwaniu teorii fundamentalnej, Warszawa 2010, p. 31.

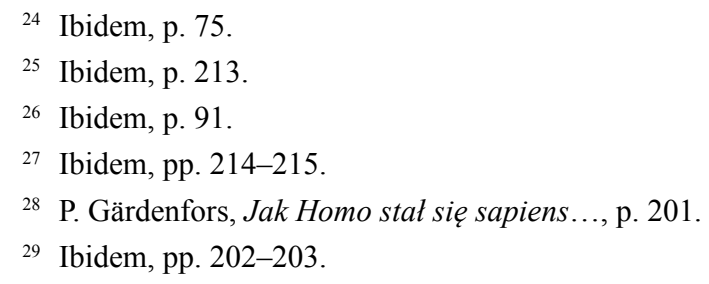




\section{Human spirit between passion and rationality}

Blaise Pascal has differentiated wisdom of the heart from the wisdom of the reason and has granted the superior meaning to the first of the two, claiming that the heart has its rationale which reason does not $\mathrm{know}^{30}$. In analysis of emotions, reason is automatically guided to heart. This line of thoughts is followed, among the others, by Daniel Goleman who states that in attempt to discover why evolution gave central role in human psyche to emotions, sociologists are indicating feelings over reason. Goleman elaborates that emotions are driving us when we have to face challenges too important to resolve them only with reason. He concludes that every insight into human nature which ignores the power of emotions is very short-sighted ${ }^{31}$.

In evolutionary context, neurobiological structures undergoing constant development worked at their best and even demographic explosion and technological progress only slightly impacted on the biological templates of emotional life ${ }^{32}$. Goleman does not dismiss reasoning values when discussing role of emotions in human life. He shows however that subject of mind requires considering the emotions and rationality with the same respect. Human mind is two-dimensional being both of heart and of reason, i.e. with emotional mind functioning sometimes impulsive and against logic and with rational mind being conscious, thoughtful, and able to reflect and to muse. There is no gap between them because they function mostly in harmony; however their reality comprehensive powers work differently and they are both independent authorities. It happens in certain situations that rational mind is not under the emotional stimuli but it is overshadowed and overwhelmed by emotional $\operatorname{mind}^{33}$. In everyday experience human mind depends on the dynamics between emotional and rational mind.

It is hard to address rationality when emotions are dismissed. In evolutionary aspect, firstly from brain stem emerged emotional centres. The oldest one is the sense of smell (main parts of olfactory brain are hippocampus and amygdala). Only later on, based on limbic system and following layers of emotional brain, rational mind (neocortex) came to existence. Neocortex allowed survival in changing environmental conditions and creation of culture and civilisation.

\footnotetext{
30 B. Pascal, Myśli, Kraków 2004, p. 74.

31 D. Goleman, Inteligencja emocjonalna. Poznań 1997, p. 24.

32 Ibidem, p. 26.

33 Ibidem, pp. 31-32.
} 
Rational mind did not repress emotional mind on the level of primates evolution but it allowed emergence of diverse, broader spectrum of emotional reactions ${ }^{34}$. Goleman postulates that amygdala and its mutual interactions with neocortex is the core of emotional intelligence ${ }^{35}$. Amygdala generating emotional reactions overwhelms reason by blocking the signals for cerebral cortex. When emotional reactions are flowing to amygdala from thalamus bypassing the cerebral cortex, memories and reactions of amygdala are memorised and might be unconsciously recreated. Evaluation of emotional reactions takes place in cerebral cortex, i.e. when the stimuli from sense organs is being send through thalamus to cerebral cortex but not to the amygdala. In frontal lobe reactions are recorded and analysed with emotions included only in critical situations. Supported by LeDoux research, Goleman claims that the main switch off for disturbing emotions seems to be frontal part of left frontal lobe ${ }^{36}$. It can be now possible to pinpoint the neurobiological interactions between rational and emotional minds to the pathways joining amygdala and cerebral cortex. There the struggle between reason and emotions is happening. Reason does not always win. Rational mind control the emotions except when it is overwhelmed by emotional mind ${ }^{37}$. This leads to situation when emotional mind is forcing the rational mind to justify emotional behaviours and create rational argumentation for undertaken decisions and acts $^{38}$.

O'Leary and Beauregard focus on Near Death Experience (NDE) and Religious, Spiritual and/or Mystic Experience originating from $\mathrm{NDE}^{39}$. This research is used by atheists to explain these experiences as a result of brain functioning. O'Leary and Beauregard claim that religion is not identical to brain functions ${ }^{40}$, as well as it is not brain artefact ${ }^{41}$. They show that NDE research despite they are being dismissed as subjective, are worthy to analyse in the context of neurosciences. They are pointing out these concepts being conform to scientific

34 Ibidem, p. 36.

35 Ibidem, p. 42.

36 Ibidem, p. 20.

37 Ibidem, p. 60.

38 Ibidem, p. 452.

39 Research on the subject carried out by scetically biased neurosurgeon can be found in: E. Alexander, Dowód. Prawdziwa historia neurochirurga, który przekroczyl granicé śmierci i odkryt niebo, Kraków 2013. This subject is very interesting for me personally as I have NDE myself.

40 D. O’Leary, M. Beauregard, Duchowy mózg. Neuronaukowa argumentacja za istnieniem duszy, Kraków 2011, p. 70.

41 Ibidem, p. 136. 
research logic and methodological requirements described by K.R. Popper (they can be falsified). O'Leary and Beauregard elaborate that Religious, Spiritual and/or Mystic Experience originating from NDE cannot be a side effect from cognitive architecture of brain, despite positivistic approach. Brain does not create spiritual experience and does not create $\operatorname{God}^{42}$. In the brain however the spiritual experience from transgression level are being reflected. Religious experience is explained in the context of religious system but they are also a subject of scientific analysis. Anna Lewandowska-Ronnegren claims that the brain is evolutionary adjusted to search and receive spiritual experience ${ }^{43}$. According to Lewandowska-Ronnegren, limbic system is responsible for positive and negative emotions, motivation and attachment and its activity is associated with religious experience. Important role is played by hippocampus (which is responsible mainly for memory and the changes in its function can result in hallucinations) and amygdala. Hippocampus and amygdala in connection to temporal lobe allow people to undergo mystical experience ${ }^{44}$.

Human spirituality is a fact but there is no basis to reduce it to neurobiological sphere. Conclusion from above analysis is to care about the development of emotional and rational brain evenly; however, not only. Presented neurobiological research findings considering Homo sapiens and Homo afectus raise hope for finding foundations for genesis of Homo religious or Homo spiritual or Homo creator hence Man's religious spirituality.

\section{Conclusions}

O'Leary and Beauregard claim that the transcendental impulse to contact God and spiritual world is one of the most basic and powerful forces observed in Homo sapiens sapiens. Because of that Religious, Spiritual and/or Mystic Experience

42 Ibidem, p. 439.

43 A. Lewandowska-Ronnegren, A., Gdzie w mózgu mieszka Bóg, "Wiedza i Życie" 2 (2017), pp. $62-65$.

${ }^{44}$ D. O’Leary, M. Beauregard, Duchowy mózg..., p. 63. In their works, Denyse O'Leary and Mario Beauregard disregard the following approaches: evolutionary biology, evolutionary psychology, genetic auto transcendence, God Helmet apparatus (brain stimulation with magnetic field), memeplex concept as per Dawkins, neuroimaging with fMRI, PET during brain focusing on prayers, EEG. 
from NDE indicate existence of a fundamental dimension of human existence ${ }^{45}$. It is a logical consequence to show and assume that brain does not generate, create but experience and transfers these experience ${ }^{46}$. Neurobiological argumentation leads to conclusion that death of the brain does not mean annihilation of the person, i.e. elimination of mind, consciousness and self. Individual minds and persons come from and are connected to the Plain of Existence (primeval form). It is timeless, non-dimensional and infinite Spirit. The mind and consciousness are most basic and irreducible qualities of the Plain of Existence ${ }^{47}$.

These analyses roots in metaphysical discussion surrounding the person phenomenon. The God, an Angel and a Man are a Person. Being a Person means communion in God. Man has been made in the image of God. Accepted definition of brain death does not correspond to the concept of human person. Despite brain death man - as a Person - continues to exist. In this sense internal organs donation has its humanitarian aspect. It became alive and personal relationship between the giver and the taker. The giver is not handing over what is no longer necessary but what stands for its personal value in the aspect of existence. The donor offers a chance of existence from the source of existence. Organ donation after stating brain death is an act made from love and is a proof of heroism. First act (of love) is an obligation; second one (heroic) is completely free and undetermined. In a situation when the revival after brain death is not possible, entire discussion regarding its relation to person in its neurobiological context is devoid of sense and meaning.

Explaining biodiversity in terms of evolution does not appeal to everyone. Using evolution in neurobiology to back up the notion that the brain creates God is an abuse. It is completely unacceptable to refer to naturalism in explanation of spiritual aspect of man and genesis of his soul. As neurobiologist, Denyse O'Leary sustains and explains scepticism towards cause and effect genesis of human soul in terms of positivist and naturalist analysis. She does not deny that spiritual sphere had no connection to previous natural order and did not express itself in natural order. Above considerations show broad spectrum of human spirituality dynamics, like: language, morality, rationality and mind. Against all conjecture, neurobiology brings Man from heavens to found him in earthly

\footnotetext{
45 Ibidem, p. 440.

46 Ibidem, p. 444.

47 Ibidem, p. 446.
} 
space-time and here the source of its dynamism and hope are emotions; sphere of feelings bringing meaning to rationality, morality and words. It is all rooted in Nature. Human dignity, the fact of existence reaches out beyond natural realm. Between these two realms exists the sphere of human spirituality.

\section{References}

Chalmers D., Świadomy umyst w poszukiwaniu teorii fundamentalnej, Warszawa 2010.

Gazzaniga M., The Law and Neuroscience, "Neuron" 60 (2008), No. 3, 412-145.

Gazzaniga M., Istota czlowieczeństwa. Co sprawia, że jesteśmy wyjątkowi, Sopot 2011.

Gärdenfors P., How Homo became sapiens. On evolution of thinking. Oxford 2006 [wyd. pol. Jak Homo stat się sapiens, Warszawa 2010].

Goleman D., Inteligencja emocjonalna, Poznań 1997.

LeDoux J., Mózgowe interakcje poznawczo-emocjonalne, in: Natura emocji, eds. P. Ekman, R. Davidson, Gdańsk 2002.

Lewandowska-Ronnegren A., Gdzie w mózgu mieszka Bóg, "Wiedza i Życie" 2 (2017), pp. 62-65.

Lorenz K., Odwrotna strona zwierciadta, Warszawa 1977.

M. Tulli Ciceronis Tusculanarum Disputationum Libri Quinque: Volume 2, Containing Books III-V: A Revised Text with Introduction and Commentary and a Collation of Numerous Mss., eds. T.W. Dougan, R.M. Henry, Cambridge 2015.

O’Leary D., Beauregard M., Duchowy mózg. Neuronaukowa argumentacja za istnieniem duszy, Kraków 2011.

Pascal B., Myśli, Kraków 2004.

Roth G., Dicke U., Evolution of the Brain and Intelligence, "Trends in Cognitive Science" 9 (2005), No. 5, pp. 250-257.

Tomasello M., Historia naturalna ludzkiego myślenia, Kraków 2015.

Vetulani J., Mózg: fascynacje, problemy, tajemnice, Kraków 2010. 


\title{
W POSZUKIWANIU BIOLOGII DUCHOWOŚCI
}

\section{Streszczenie}

W kontekście procesów ewolucji mózgu wzgórze odgrywa istotną rolę w kształtowaniu się duchowości. Struktura i funkcja mózgu zwierzęcia i człowieka wykazują ewolucyjny przeskok między okolicą podoczodołową a korą przedczołową, co daje podstawę poszukiwania $\mathrm{w}$ tych rejonach duchowości ludzkiej. Neuronaukowcy nie tylko wiążą duchowość człowieka z ewolucją i rozwojem mózgu, ale także dopatrują się w jego strukturach podstaw moralności i sumienia.

Slowa kluczowe: neurobiologia, duchowy mózg, ewolucja, neurobiologia moralności

\section{IN SEARCH SPIRITUALITY BIOLOGY}

\begin{abstract}
Summary
In the context of brain evolutionary processes, thalamus plays important role in shaping of spirituality. Animal and human brain structure and function shows evolutionary leap between infraorbital region and prefrontal cortex which gives foundation for searching there human spirituality. Neuroscientists does not only associate human spirituality with brain evolution and development but also see foundations of morality and consciousness in its structures. Recent neurobiological research results are very insightful in what used to be exclusively philosophical area of expertise. Considerations presented in the article include language, morality, rationality and mind in context of evolution.
\end{abstract}

Keywords: neurobiology, spiritual brain, evolution, neurobiology of spirituality 